\title{
Tumor Necrosis Factor Receptor Superfamily Member 18
}

National Cancer Institute

\section{Source}

National Cancer Institute. Tumor Necrosis Factor Receptor Superfamily Member 18. NCI Thesaurus. Code C105568.

Tumor necrosis factor receptor superfamily member 18 (241 aa, $26 \mathrm{kDa}$ ) is encoded by the human TNFRSF18 gene. This protein is involved in T-cell-mediated immune function. 